\title{
Management of allergic stomatitis due to daily food consumption(Penatalaksanaan stomatitis alergika akibat konsumsi makanan sehari-hari)
}

\author{
${ }^{1}$ Erni Indrawati, ${ }^{2}$ Kus Harijanti \\ ${ }^{1}$ Student at Oral Medicine specialist program \\ ${ }^{2}$ Department of Oral Medicine \\ Faculty of Dentistry, Airlangga University \\ Surabaya, Indonesia
}

\begin{abstract}
ABSTRAK
Stomatitis alergika atau stomatitis venenata merupakan suatu reaksi hipersensitivitas yang disebabkan oleh alergen penyebab yaitu obat-obatan, makanan, bahan kedokteran gigi (bahan restorasi, prostetik, alat ortodonti, merkuri, akrilik, cobalt). Pada kasus ini akan dibahas mengenai stomatitis alergika karena makanan. Makanan yang paling sering menyebabkan alergi pada penderita dewasa yaitu jeruk (citrus fruit), kacang, ikan, ikan laut dan gandum. Manifestasi oral dari stomatitis alergika diawali dengan adanya vesikula multipel yang akan menjadi ulser yang tertutup fibrin dengan tepi erythematous disertai dengan inflamasi dan rasa nyeri. Pasien adalah seorang wanita berusia 53 tahun yang sering menderita sariwan sejak 6 bulan yang lalu, sudah berobat ke dokter gigi praktek swasta maupun dokter gigi praktek pemerintah (RSUD dan Puskesmas). Pasien mempunyai riwayat alergi. Pada pemeriksaan intra oral didapatkan adanya ulser multipel pada mukosa pipi kanan atas, mukosa pipi kanan bawah dan lidah. Kasus didiagnosis sebagai stomatitis alergika karena makanan berdasarkan anamesis, pemeriksaan klinis dan pemeriksaan laboratorium. Pengobatan utama dengan menghindarkan faktor penyebab, pemberiaterapi simptomatis, dan pemberian kortikosteroid topikal. Disimpulkan bahwa penatalaksanaan stomatitis alergika dengan menghindarkan faktor penyebab makanan, pemberian obat kumur yang mengandung analgesik/anti-inflamasi, dan pemberian obat kortikosteroid topikal.
\end{abstract}

Kata kunci: stomatitis alergika, makanan

\begin{abstract}
Allergic stomatitis or stomatitis venenata is a hypersensitivity reaction caused by an allergen from medicines, foods, dental materials (restoration material, prosthetic, orthodontic appliance, mercury, acrylic, cobalt). This report will discusses the management of food allergic stomatitis. The common cause of food allergy in adult patients are orange (citrus fruit), nuts, fish, marine fish and wheat. Oral manifestations of allergic stomatitis begin with multiple vesicles and becomes fibrin-covered ulcers with erythematous edges accompanied by inflammation and pain. The patient was a 53-year-old woman who has suffered stomatitis since 6 months ago, and had seen dentist in private practice and government dental-practice (hospitals and health centers). The patient has an a allergy history. Intra oral examination found the presence of multiple ulcers on the buccal mucosa upper right, cheek mucosa lower right and tongue. The final diagnosis of the case is allergic stomatitis due to daily food alergic base on anamesis, clinical examination and laboratory tests. Treatment to prevent allergic stomatitis causes, symptomatic therapy, and topical corticosteroids. It was concluded that management of allergic stomatitis should avoid the food as primary causes, giving mouthwash containing analgesic/anti-inflammatory and topical corticosteroids.
\end{abstract}

Key words: allergic stomatitis , daily food consumption

Correspondence: Erni indrawati, Department of Oral Medicine, Faculty of Dentistry, Airlangga University, Jln. Prof. Dr. Moestopo No.47, Surabaya, Indonesia.60132.E-mail: erniindrawatidrg@gmail.com

\section{INTRODUCTION}

Allergy was derived from "allos" whichmeans a deviation from original manner. ${ }^{1}$ Allergen was a foreign object that makes alteration. ${ }^{1}$ Symptom caused by food allergies varies from small reddish papules to form a life-threatening condition namely fatal anaphylaxis, mostly involving "the target organs" i.e. skin, gastrointestinal tract, and upper and lower respiratory tract. Severity of allergic reactions from food showed no stereotypical. Each individual also has the distinction of the allergens that cause allergic reactions. ${ }^{2}$

Coombs and Gell classified allergen into 4 types of hypersensitivity reactions that have been revised by Janeway and Travers in 1995, namely Type I reactions oranaphylaxisreaction, type II or cytotoxic, type III or complex reaction-toxic, and type IV or reaction cell, which is divided into 3 types, IVa, IVb, IVc. The latter allergy is often called as delayed hypersensitivity reactions due to occurrence of more than 12 hours after antigen exposure. ${ }^{1}$ This type does not involve antibodies but involving $\mathrm{T}$ lymphocytes because T-lymphocytes has sensitisation reacts with a particular antigen and produces immune reaction. ${ }^{2}$ Type IVa hypersensitivity reactions make tissue damaged that is caused by stimulation of macrophage activation of Th1 cells and result in inflammation. In type IVb hypersensitivity reaction, tissue damage 
is caused by the activation of $\mathrm{TH} 2$ cells that cause inflammation. In this mechanism, eosinophils have an important role that can cause tissue damage. While in the type IVc hypersensitivity reactions, tissue damage is caused by the activity of T-cytotoxic cells, and $\mathrm{CD} 8^{+}$.

Allergic stomatitis or venenata stomatitis is a hypersensitivity reaction that can be caused by allergens, such as drugs, food, and dental materials (restoration, prosthetic, orthodontic appliance, cobalt, mercury, acrylic). Allergic stomatitis is also called "allergic mucositis" as type III/IV of hypersensitivity reaction. ${ }^{3,4}$ Oral manifestation of allergic stomatitis begins with multiple vesicles that would be fibrincovered ulcers with erythematous with inflammation and pain. The most common location is on the buccal mucosa, gingiva, labial mucosa, lips and tongue, but it can occurs in all parts of the oral cavity. The most frequent allergic reactions are shellfish, citrus fruits, chocolate or drug. ${ }^{3}$ Previous studies show the most frequently mentioned causes of food allergies are fish, eggs, milk, chocolateand nut. ${ }^{1}$ It can also happen due to the additional preservatives in these foods. ${ }^{2}$

Treatment of allergic stomatitis is to avoid the allergen and use antihistamin. In other literature states allergic diseases can be treated with corticosteroids, immunosuppressants, and antihistamin. ${ }^{3}$ The initial generation of antihistamines generally have a great sedative effect while the second-generation of antihistamines have a side effect to occurrence of cardiac arrhythmias. ${ }^{6}$ Selecting antihistamine should consider the least side effects. Side effects of longterm antihistamine will reduce the effectiveness of antihistamines. Corticosteroid is a hormone produced by the adrenal gland cortex. The use of exogenous corticosteroids has an effect of anti-allergy, antiinflammatory, immunosupressan, and metabolic. Side effects of corticosteroid will cause a pressure of immune response to the host so an infection will be susceptible and wound healing process becomes longer. ${ }^{7}$

Diagnosis of allergy was based on a history of allergic diseases, clinical examination and laboratory examination. Individuals with a clinical history of this disease have positive mark on immunoglobulin E.
To determine the exact allergen, the skin test was examined using rub test, pricke test, test strach, intracutaneus test, patch test or examination in vitro. Examination was possible ifa skin test or provocation was impossible (pregnancy, baby, treatment, active disease) and in vivo test results was not clear. ${ }^{8}$

The purpose of this article is to report the management of allergic stomatitis in patient with a history of food allergies.

\section{CASE}

A 53-years-old lady who is a soy sauce factory office employees came to the Oral Medicine Clinic of Dental Hospital Airlangga University with a chief complaint of ulceration on the right side of the tongue since a week ago, often recure in 6 months, and pain when eating. The siblings of patient suffer allergies on skin manifestations. Three months ago, when the patient came to the dentist with the chief complaints of ulceration, occlusal grinding was performed because the ulceration is located close with sharp teeth. After the occlusal grinding, the ulceration was healed. After 1 week, the ulceration recurred, so the patient checked at Sidoarjo Dental Hospital and got prescription Aloclair therapy plus gel. After that ulceration healed within a few days.

One month later, the ulceration recurred in different areas, and she came to JAMSOSTEK and got prescription of Aloclair therapy plus oral rinse. The patient recovered, but 1 month after mouthwash finished, patient suffered ulcers again, was examined in the health center and got prescription multivitamins (patient forgot their name) and the patient recovered from the mouth ulcer.

Extra oral examination on the submandibular gland, on palpation of the left and right was palpable, tender, sore, normal temperature, normal color, and can be driven. On intra oral examination, found white multiple ulcer in the upper right buccal cheek mucosa. The ulcer is painless and has $2-3 \mathrm{~mm}$-diameter with irregular border. The examination on the lower right cheek mucosa showed white ulcers with irregular border, diameter $3 \mathrm{~mm}$, painless. While on the tongue it showed white ulcer with irregular border, diameter $6 \mathrm{~mm}$, and painful (Fig 1).

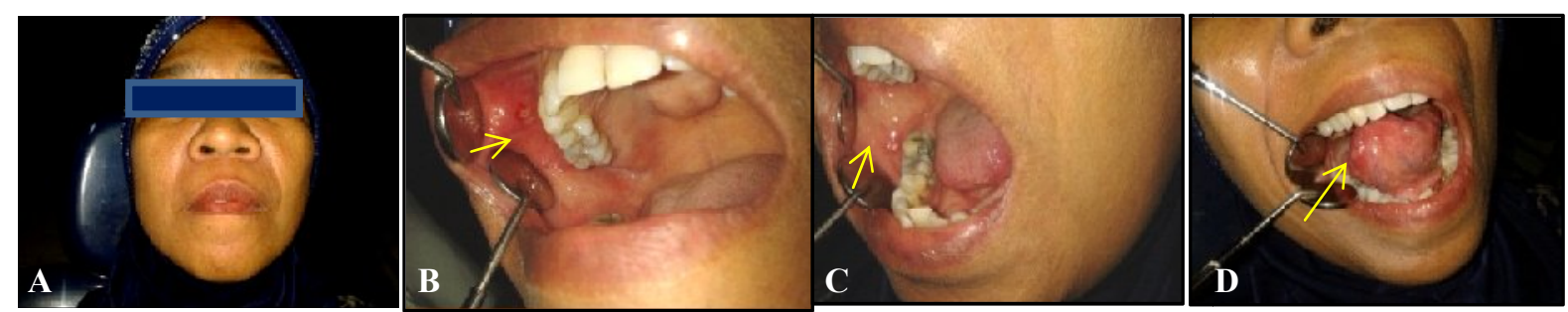

Figure 1 A Extra oral examination; B white ulcer in the upper right buccal mucosa; $\mathbf{C}$ white ulcer on the lower right buccal mucosa; $\mathbf{D}$ white ulcer on the tongue. 

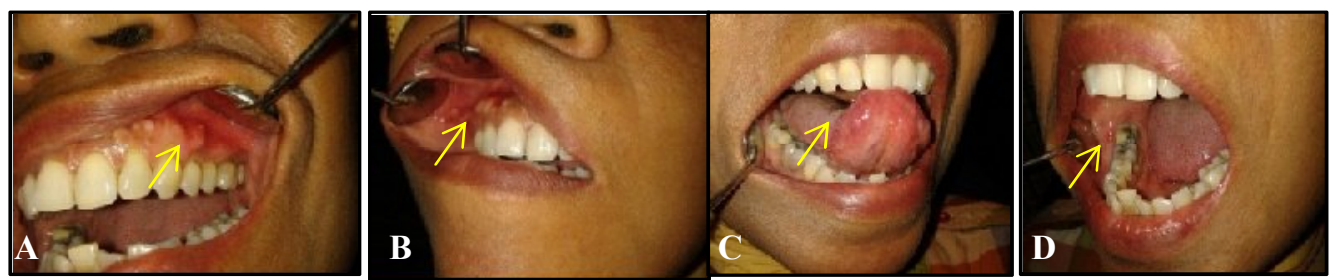

Figure 2 A Fold on the left buccal ulcers obtained white with reddish border, B Ulcer in the upper right mucosa buccal, $\mathbf{C}$ ulcer at tongue macular, $\mathbf{D}$ painless ulcer in the lower right mucosa buccal.

The type of the above case, based on clinical examination and diagnosis is the recurrent aphthous stomatitis herpetiformis with differential diagnosis of allergic stomatitis.

\section{MANAGEMENT}

The patient was referred to Clinical Pathology laboratory to perform a complete blood count (CBC), renal and liver physiology tests, examination of blood glucose test, and total IgE. The patient was instructed to maintain a hygiene oral cavity and got prescriptions three-times-a-day mouthwash (Aloclair plus oral rinse $^{\circledR}$ ) and once-a-day multivitamin (Theragran ${ }^{\circledR}$ ).

Patient who was recalled after a week, brought the result laboratory examination test. After 4 days, the patient was feeling comfortable. The drug has been consumed following the prescription, mouthwash was finished, and multivitamins was extant. Patient came with the results of laboratory tests and the photocopy of laboratory results are enclosed.

Extra oral examination found left and right side submandibular gland on palpation palpable, tender, sore, normal temperature and color, can be driven.

Intra-oral examination was found ulcer in the upper right mucosa buccal with characteristic white with irregular border, diameter $4 \mathrm{~mm}$, pain. In the lower right mucosa buccal are shallow white ulcers 1-mm diameter, painless. At tongue macular reddish color obtained a 2-mm diameter edge irregular, and painless. Fold on the left buccalulcers obtained white with reddish border, irregular border, 2-mm diameter, and was painful (Fig 2).

Patient was encouraged to take take most care of her oral hygiene and avoiding allergen-suspected foods. The patient was given three-time-a-day 10 $\mathrm{mL}$ mouthwash (Aloclair plus oral rinse ${ }^{\circledR}$ ) and oncea-day multivitamin $\left(\right.$ Theragran $^{\mathrm{a}}$ ).

The patient was referred to Prick test (skin prick test) in UPF Allergy Dermatology Dr. Soetomo and was scheduled for another control in next week.

On the third visit, eight days after first evaluation, patient felt comfortable, and the ulcers found which reappeared on the left tongue were painless. Aloclair mouthwash finished, multivitamin still remained and extant. Patient came with the following results of laboratory Pricle tests: cotton +3 , beef +3 , chicken +4 , egg white +3 , duck egg yolk +3 , and cob +3 .

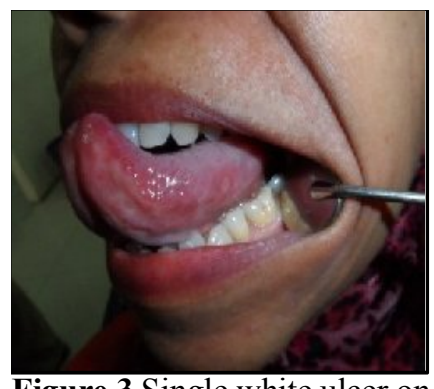

Figure 3 Single white ulcer on the left side of tongue

Extra oral examination of sub-mandibular gland on palpation of the right and left found palpable, rubbery, painless, of normal color temperature, and is movable. While intra-oral examination on the left tongue found single white ulcer with reddish border, irregular border, diameter $4 \mathrm{~mm}$, painless (Fig 3).

The patient was encouraged to continue taking multivitamin, optimizing oral hygiene, and avoid the stomatitis triggering foods. The patient was gave a prescription: three-time-a-day mouthwash $10 \mathrm{ml}$ (Aloclair plus oral rinse ${ }^{\circledR}$ ).

On the fourth visit, $14^{\text {th }}$ days after the second evaluation, because patient get permission from work only on that date. Mouthwash and multivitamins were finished, patient felt comfortable before the painfull ulcer reappeared on the tongue 3 days ago. While the painful ulcer appeared inside the lips 3 days ago. The anamesis showed that patient consumed foods that contain chicken flavoring.

Extra oral examination of submandibular glands found the right and left was palpable, soft, painfull, normal temperature and color, and was movable. While the intra-oral examination on the left buccal mucosa found withulcerwithreddish irregularborder, 4-mm diameter and was painless. At the tip of the tongue found white ulcers with reddish irregular border, 2-mm diameter and was painless. On the left side tongue it was found ulcer with reddish border which had 1-mm diameter and was painless (Fig 4).

The patient was prescribed a three-time-a-day 10 $\mathrm{mL}$ mouthwash (Aloclair plus oral rinse ${ }^{\circledR}$ ), and once-a-day multivitamin $\left(\operatorname{Theragran}^{\circledR}{ }^{a}\right.$ ) and topical 


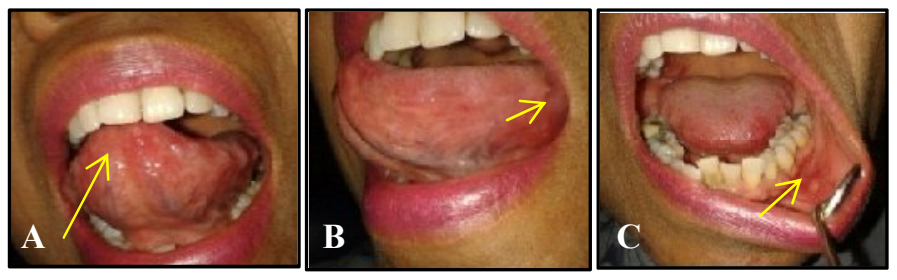

Figure 4 A At the tip of the tongue found white ulcers, $\mathbf{B}$ the left side tongue it was found ulcer, $\mathbf{C}$ on the left buccal mucosa found with ulcer

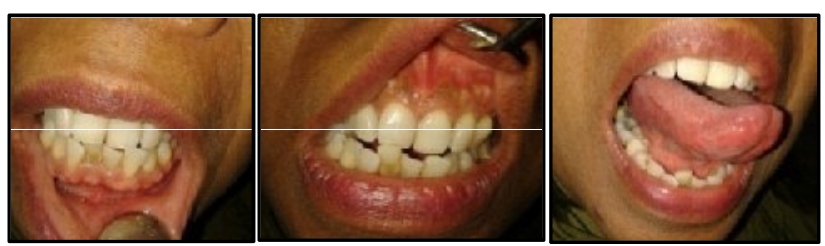

Figure 5 The ulcers were totally healed

corticosteroid (Kenalog in ora base tube ${ }^{\circledR}$ ). Patient was advised to avoid ingredients that trigger allergies, keep mouth cavity hygiene, use mouthwash, topical medications and multivitamins regularly. The patient was scheduled next week for the next evaluation.

On the fifth visit, fourteen days after the third evaluation, patient felt comfortable, avoiding all the ingredients that cause the allergies. Patient stopped mouthwash due to ulcer have healed and had no pain. The patient was able to eat and drink comfortably.

Extra-oral examination found the left and right mandibularglands not palpable, not painful anymore when palpated, whereas intraoral examination found oral mucosa normal and the ulcers were totally healed (Fig 5). The patient was declared cured and therapy discontinued.

\section{DISCUSSION}

53-year-old female patient, a soy sauce factory worker, came to the Dental Hospital of Airlangga University with chief complaint of multiple ulcers throughout her oral cavity. Recurrent ulcer began 6 months ago, but previously the patient rarely hadulcer.

Drugs that have been used were Aloclair gel and oral rinse, and also grinding oclusal treatment to treat dental trauma that was suspected as the cause. The siblings of patient suffered allergy that manifestated on skin.

The anamesis and clinical examination at the first visit showed the temporary diagnosis was recurrent aphthous stomatitis with herpetiformis; differential diagnosis was stomatitis alergica. Based on anamnesis, patient often suffered stomatitis that recurred with the frequency of recurrence since 6 months ago. The clinical examination showed multiple ulcers with a diameter of 2-3 $\mathrm{mm}$ on the right upper and lower mucosa buccal and also on the tongue. Differential diagnosis of this case was allergic stomatitis. The
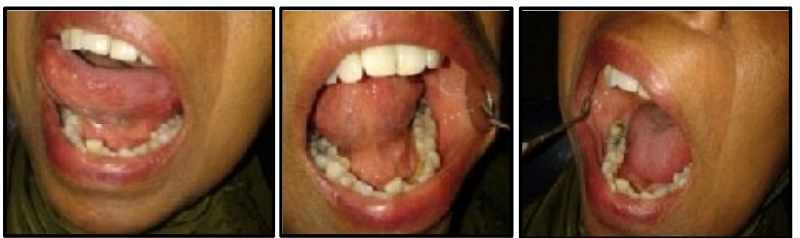

equation was the existence of multiple ulcers with a diameter of 1-3 $\mathrm{mm}$, has no prodromal symptoms and is recurrent. While the difference was that allergic stomatitis may occur on keratinized mucosa and the nonkeratinized, spread ulcer location. Herpetiformis type of recurrent stomatitis aphthous only occurs in the keratinized mucosal commonly in the buccal mucosa, labial mucosa, and lateral dorsum of the tongue, ${ }^{5}$ as clustered ulcers. Oral manifestation of allergic stomatitis was preceded by the formation of multiple vesicles that will form the ulcer, whereas in SAR herpetiformis-type the vesicle formation was not found, and the clinical manifestations found an ulcer. $^{3}$

Aloclair $^{\circledR}$ mouthwash therapy and Theragran ${ }^{\circledR}$ multivitamins were given on first visit. Mouthwash contains aloe vera, sodium hyaluronate, glycyrhetinic acid, polyvinylpyrolidone (PVP) agent which is symptomatic therapy functions as anti-inflammatory, antiseptic, and analgesic. ${ }^{15}$ Anti-inflammation was given to reduce inflammation, and antiseptic function prevent secondary infection due to the disintegration of the mucosa (multiple ulcer) which will be the port d'entry of various micro-organisms, while analgesics was gave to relieve pain.

Theragran-M was a multivitamin tablet which contains $10,000 \mathrm{IU}$ vitamin $\mathrm{A}, 10 \mathrm{mg}$ vitamin $\mathrm{B} 1,5$ $\mathrm{mg}$ vitamin B6,5 $\mu \mathrm{g}$ vitamin $\mathrm{B} 12,200 \mathrm{mg}$ vitamin $\mathrm{C}$, $400 \mathrm{IU}$ vitamin D, $20 \mathrm{mg}$ Ca pantothenate, $150 \mu \mathrm{g}$ Kiodide, $12 \mathrm{mgFe}, 64 \mathrm{mgMg}, 1 \mathrm{mg}$ manganase, $2 \mathrm{mg}$ copper, and $1.5 \mathrm{mg} \mathrm{Zn}$. Vitamin A was required for differentiation and growth of epithelial tissue and improveimmune systemfunction. Vitamin B complex is a coenzyme in the many biochemical reactions in the body which converts carbohydrates into glucose and then into energy, which ultimately accelerates the metabolism of the human body and increase the stamina of the body. Vitamin $\mathrm{C}$ or ascorbic acid has 
an important role as a cofactor in the hydroxylation of proline residues in collagen synthesis. Vitamin C is also helpful to maintain connective tissue and helps connective tissue synthesis during the healing. ${ }^{17}$ Multivitamins is expected to improve the general condition of the patient. On the first visit the patient was referred for $\operatorname{IgE}$ examination and a complete blood count because, based on anamesis, patient had a history of allergies. Complete blood examination functions to establish the diagnosis and determine the treatment.

On the 2nd visit (first evaluation), patient came with the results of laboratory tests which shows abnormal eosinophils $(5 \%$, normal value around 2$4 \%$ ), the LED $50 \mathrm{~mm} /$ hour (normal values around 0-30 mm/hour), direct LDL cholesterol $152 \mathrm{mg} / \mathrm{dl}$ (normal values around $<100 \mathrm{mg} / \mathrm{dl}$ ), total IgE 147 $\mathrm{IU} / \mathrm{ml}$ (normal value $<87 \mathrm{IU} / \mathrm{ml}$ ).

The increase of eosinophils showed an allergic reactions and parasitic infections (especially worms) in the body. While an increasing number of LED was due to increased plasma viscosity (eg due to an increase in cholesterol and fats) will lead to the attraction of the growing. ${ }^{12}$ IgE was responsible for hypersensitivity reactions, including anaphylactic and atopic reactions. In these patients found that the amount of IgE was increased. Some literatures stated normal $\mathrm{IgE}$ value are between 17-240 $\mathrm{ng} / \mathrm{mL}(2.4$ $\mathrm{nL} / \mathrm{mL}=1 \mathrm{IU} / \mathrm{mL}$ ), while on the other literatures mentioned normal IgE values are $0-120 \mathrm{IU} / \mathrm{ml} .{ }^{1}$ The increasing total of $\operatorname{IgE}$ in the patient due to hypersensitivity. ${ }^{9}$ Increasing levels of IgE can also be found in parasitic infection, pulmonary aspergillosis, congenital immunodeficiency immunosuppressants, the reaction graph-versus-host, and HIV/AIDS. On the second visit, the patient was referred to Prick test to determine the allergic ingredients that trigger the appearance of ulcers.

On the third visit (second evaluation), patient brought the results of laboratory skin Prick test which showed that the patient was hypersensitive to some types of allergen. In assessing the size of the bumps (wheals) namely that a value of 0 means there is no reaction, $1+$ was characterized by $1 \mathrm{~mm}$ bumps, larger than the control, $2+$ was characterized by the presence of 1-3 mm bumps, larger than the control value, 3+ was characterized by the presence of 3-5 $\mathrm{mm}$ bumps, greater than control value, and 4+ characterized by $5 \mathrm{~mm}$ bumps that larger than the control value and presence of erythema.

The greater value of the test results will result in greater sensitivity to these allergens, but not always describethe severity of clinical symptoms. A positive reaction will usually be followed with itches 30-60 minutes after test. ${ }^{9}$ In this case report the patient had an allergy to chicken meat, egg white, egg yolk duck, cob, cotton, and beef. Chicken meat allergy as shown in Prick test results +4 will cause the most severe clinical symptoms of allergies among other materials. Allergy to chicken meat was rare. In patient with a history of chicken meat allergy was common egg allergy. ${ }^{14}$ The patient was instructed to avoid all allergens according to the results of Prick test and to optimize oral hygiene to prevent the recurrence of allergic stomatitis.

Based on the anamesis, clinical examination and laboratory tests in this case definitely diagnosed as allergic stomatitis.

On the fourth visit or third evaluation, ulcer reappeared on the left buccal mucosa, tongue tip and left side, because patient had consumed foods that contain chicken flavoring. Patient was given Aloclair mouthwash, Theragran multivitamin and topical corticosteroids which is Kenalog in orabase paste that contain triamcinolone acetonide $0.1 \%$ in an emollient dental paste. Triamcinolone acetonide has 9-fluoro-11 $\beta, 16 \alpha, 17,21$-tetrahydroxypregna-1, 4diene-3,20-dione cyclic 16, 17-acetal structure with acetone. Kenalog in orabase contains $1 \mathrm{mg}$ pasta of triamcinolone acetonide with gelatin, pectin and sodium carboxymethyl cellulose in Plastibase, polyethylene and mineral oil gel base. Triamcinolone acetonide has anti-inflammatory effects, anti-pruritic, and as vasoconstriction. The side effect of topical corticosteroids was tachyphylaxis symptoms that decrease the response of skin/mucosa against glucocorticoid medication because of repeated drugs of tolerance. It means that vasocontriction effect disappeared. Application of topical corticosteroids at least 4-6 weeks to steroids for weak potency steroids and at least 2 weeks for strong potent one.

On the fifth visit (fourth evaluation), patient felt comfortable. All ulcers in oral cavity disappears. Patient avoided all foods and ingredients that cause allergies. Patient was advised to do desensitisation towards food causing allergies and to avoid the ingredients that triggs allergies for 3-4 weeks ${ }^{19}$ then to perform provocation with beef that was proven to have the smallest prick test result. For every provocation one type of with the same amount commonly consumed by patient. Provocation can be earned out in patient's house, but if the symptom of allergies, and allergic stomatitis, reappeared the patient should stop food provocation and ask for treatment. All the symptoms were recorded based on the time the reaction appeared. ${ }^{20}$ In the food provocation test, patient should be explained about its complications especially anaphylactic reaction 
and was instructed to visit the nearest health facility immediately.

The clinical diagnosis of this case was allergic stomatitis. In this case study there was type IVb1 hypersensitivity reaction as stated by Gell and Commbs as revised by Janeway and Travers. ${ }^{1,11}$ Type IVb hypersensitivity reaction involved $\mathrm{TH} 2$ cells in the immune system, and the antigen presented in the form of soluble antigen stimulation of $\mathrm{T}$ cells. Mechanism of type IVb hypersensitivity reactions was allergen enters the body and diffuses through the mucosal surface therefore triggering a $\mathrm{TH} 2$ reaction. Naive $\mathrm{T}$ cell differentiation into $\mathrm{TH} 2$ was assisted by IL-4/IL-13, and IL-5. The specific TH2 for an allergen produced IL-4/IL-13, and IL-5 which serve to stimulate specific $\mathrm{B}$ cells to produce specific $\operatorname{IgE}$. IgE which was produced as as a response to allergen will be bound to a receptor that is tied to activated eosinophils as effector cells and mediated by the inflammatory mediators: cytokines IL-4/IL-13 and IL-5. IL-4 function to stimulate and enhance the TH2 cell responses whereas IL-5 has the function to increase the production and activation eosinofil. In this case the results of laboratory tests found levels of $\operatorname{IgE}$ and eosinophils increased.

In conclusion, the management of allergic stomatitis should (1) avoid the allergen-causing foods based on prick test: chicken, cotton, beef, egg white, egg yolk duck, tuna; (2) give mouthwash containing analgesic/anti-inflammatory,topical corticosteroid and multivitamin, and (3) maintain oral hygiene to help the healing process and reduce the clinical symptoms.

\footnotetext{
AKNOWLEDGEMENT

The author would like to thank the Oral Medicine Departement from Faculty of Dentistry Airlangga University for the opportunity, guidance and facilities for the writing of this case report.
}

\section{REFERENCES}

1. Murphy. Janeway's Immunobiology. 7 Ed. Garland Sciense; 2008. p. 555-81

2. Nelson HS. Evaluation of devices for skin prick testing. J Allergy Clin 1998; 101: 153

3. Langlais, RP. Color atlas of common oral diseases. $2^{\text {nd }}$ Ed; 1994. p. 2-4, 140

4. Judarwanto W. Gangguan kesehatan gigi, kesehatan mulut dan alergi makanan; Children Allergy Center, Jakarta; Available at: http://childrenallergyclinic.wordpress.com. Accessed on November 2013

5. Field L. Tyldesley's oral medicine. $5^{\text {th }}$ Ed. Oxford: Oxford University Press; 2003. p.51

6. Greenberg. Burket's oral medicine. $11^{\text {th }}$ Ed. BC Decker Inc. Hamilton; 2008. p. 42.

7. Sastrowardoyo W. Peran antihistamin dan kortikosteroid dalam menanggulangi reaksi alergi. Seminar Allergy in Dentistry (5 Mei 2007)

8. Retnowati E. Peran pemeriksaan laboratorium pada diagnosis reaksi alergi. Seminar Allergy in Dentistry (5 Mei 2007)

9. Scully C, Felix DH. Aphthous and other common ulsers. Br Dent J 2005; 199: 259-64

10. Jetschow E. Food allergy. Available at: www.medicalnewstoday.com. Accessed on October 2013

11. Baratawidjaja KG, Rengganis I. Imunologi dasar. Edisi ke-10. Jakarta: Fakultas Kedokteran Universitas Indonesia; 2012. p.369-89

12. Sutedjo. Buku saku mengenal penyakit melalui hasil pemeriksaan laboratorium. Bandung: Amara Books; 2008. p.32-41

13. Steinman H. Oral allergy syndrome, what's new. Current Allergy Clin Imunol 2009; 22(2)

14. www.health.howstuffworks.com/disease-conditions/allergies/foodallergies. "what are some chicken allergy symptoms?" Accesed on October 2013

15. Gunawan A. Peranan Aloclair dalam penanganan stomatitis. Seminar Ilmiah Oral Medicine (SINOM) 2013, Surabaya

16. Soegiarto G. Rationals of topical and systemic corticosteroid therapy in oral mucosal inflammation. Seminar Ilmiah Oral Medicine (SINOM) 2013, Surabaya

17. Singh S. Pharmacology for dentistry. New Delhi: New Age International; 2007. p. 383-90

18. Mafthuhah. Oral Corticosteroid.2009. Fakultas Kedokteran Universitas Mataram. Available at http:/www.sribd.com/ doc/13461799/kortikosteroid-topikal. Accessed on Februari 2014

19. Christanto A. Uji diagnostik alergi makanan. 2011. Cermin Dunia Kedokteran 187. Available at www.kalbemed.com. Accessed on Februari 2014

20. Arwin. Buku ajar alergi imunologi anak. Ikatan Dokter Ahli Anak Indonesia; 2010. p.454 